\title{
What's Insurance to a Modern Economy?"
}

\author{
Patrick M. Liedtke ${ }^{1}$ \\ The Geneva Association, 53, rte de Malagnou, 1208 Geneva, Switzerland. \\ E-mail: patrick_liedtke@genevaassociation.org
}

Insuring risks in a modern economy is a multi-dimensional undertaking. It is a complex business that interacts with many aspects of our lives. The importance of the insurance industry for an economy can only in part be measured by the sheer size of its business, the number of its employees in a given country, the assets under management, or its contribution to the national GDP. It actually plays a more fundamental role in the workings of a modern society, being a necessary precondition for many activities that would not take place were it not for insurance. Insurance is a key component of economic development and this article is concerned with the contributions that insurance makes to the development of a modern economy.

The Geneva Papers (2007) 32, 211-221. doi:10.1057/palgrave.gpp.2510128

Keywords: insurance; economic development; risk management

\section{The size of the insurance industry}

It is important to remember just how large the insurance sector is. According to Swiss $\mathrm{Re}^{2}$ worldwide insurance premia in 2005 amounted to USD 3,426 billion, of which USD 1,452 billion were in non-life insurance. Insured losses from natural catastrophes and man-made disasters alone reached a record USD 80 billion in 2005 (see Graph 1), mainly due to the very heavy losses from hurricanes in the U.S. and the Caribbean. As the graph clearly shows, this figure varies from year to year, but there seems to be a clear upward trend, above and beyond the growth of world GDP, which some experts put at 5 per cent per annum in real terms.

If 2005 was heavily influenced by the hurricane season in North America, the previous year, 2004, pointed to another phenomenon. Owing to the Asian tsunami of December 2004, the difference in distribution between financial losses and human fatalities became especially apparent. Graph 2, based on figures taken from

\footnotetext{
* This article is based on the research carried out at The Geneva Association under the Insurance Economics Research Programme. The author would like to thank the commentators and reviewers for their helpful input, especially at an early stage for a speech given at the seminar on "Assurance, réassurance, une autre contribution au développement" held on 14 June 2005 at the French Federation of Insurance Companies (FFSA) in Paris, and then to the subsequent publication of an intermediate version in the French insurance journal Revue Risque.

${ }^{1}$ Secretary General and Managing Director, The Geneva Association. The Geneva Association is the world's leading insurance research centre supported by the private insurance industry. It is a non-profit organization and its members are the 80 (statutory maximum) Chief Executive Officers from the most prominent insurance companies worldwide. For further information, visit www.genevaassociation.org

${ }^{2}$ Swiss Re (2006).
} 


\section{USD bn, at 2005 prices}

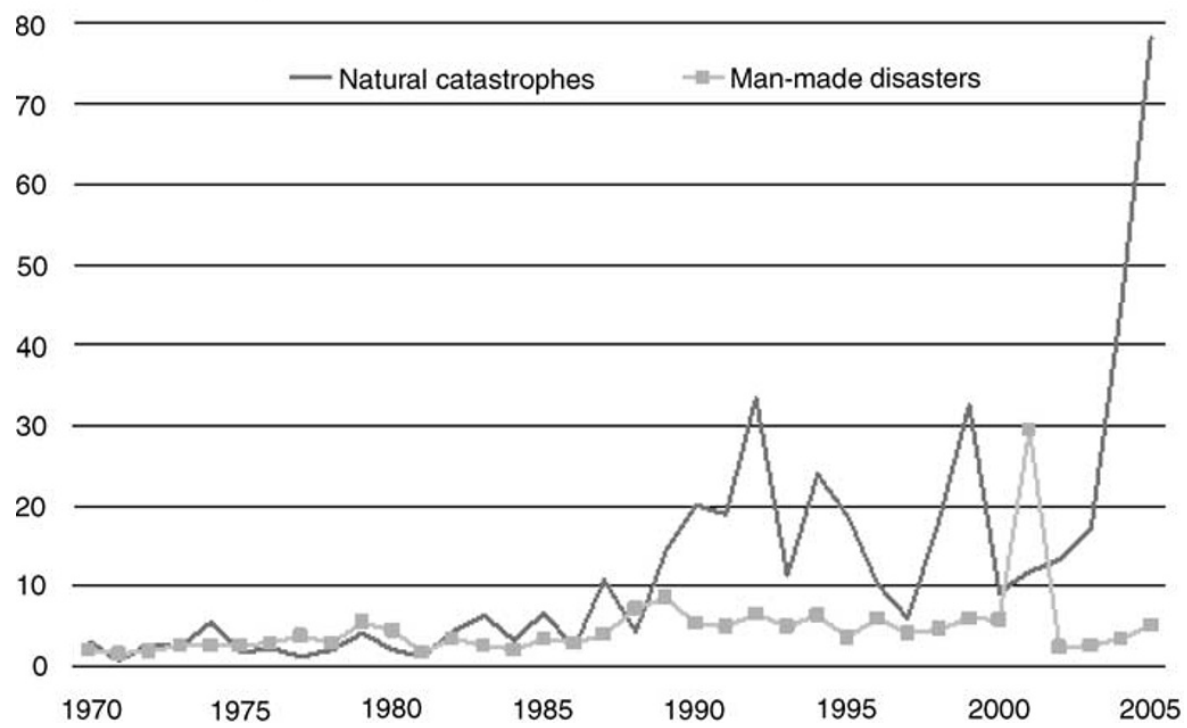

Graph 1. Insured losses 2005. Source: Swiss Re, Sigma 5/2006.

\begin{tabular}{|c|c|c|c|c|c|c|}
\hline Region & Nr. & in percent & Victims & in percent & \begin{tabular}{|c|} 
Ins.Loss \\
(m US\$)
\end{tabular} & $\begin{array}{r}\text { in per } \\
\text { cent }\end{array}$ \\
\hline Europe & 46 & $\begin{array}{r}13.9 \text { per } \\
\text { cent }\end{array}$ & $\begin{array}{l}1042 \\
\end{array}$ & $\begin{array}{r}0.3 \text { per } \\
\text { cent }\end{array}$ & 1'203 & $\begin{array}{r}2.5 \text { per } \\
\text { cent }\end{array}$ \\
\hline North America & 46 & $\begin{array}{r}13.9 \text { per } \\
\text { cent }\end{array}$ & $7 \cdot 342$ & $\begin{array}{r}2.4 \text { per } \\
\text { cent }\end{array}$ & $32 ‘ 911$ & $\begin{array}{r}67.7 \text { per } \\
\text { cent }\end{array}$ \\
\hline South America & 16 & $\begin{array}{r}4.8 \text { per } \\
\text { cent } \\
\end{array}$ & 718 & $\begin{array}{r}0.2 \text { per } \\
\text { cent }\end{array}$ & 2 & $\begin{array}{r}<0.1 \text { per } \\
\text { cent }\end{array}$ \\
\hline Asia & 169 & $\begin{array}{r}50.9 \text { per } \\
\text { cent }\end{array}$ & $290^{\prime} 412$ & $\begin{array}{r}96.0 \text { per } \\
\text { cent }\end{array}$ & $12^{\prime} 094$ & $\begin{array}{r}24.9 \text { per } \\
\text { cent }\end{array}$ \\
\hline Africa & 36 & $\begin{array}{r}10.8 \text { per } \\
\text { cent }\end{array}$ & $2 ' 666$ & $\begin{array}{r}0.9 \text { per } \\
\text { cent }\end{array}$ & 1'203 & $\begin{array}{r}2.5 \text { per } \\
\text { cent }\end{array}$ \\
\hline Oceania & 5 & $\begin{array}{r}1.5 \text { per } \\
\text { cent }\end{array}$ & 39 & $\begin{array}{r}<0.1 \text { per } \\
\text { cent }\end{array}$ & 1'261 $^{\prime}$ & $\begin{array}{r}2.6 \text { per } \\
\text { cent }\end{array}$ \\
\hline Oceans/space & 14 & $\begin{array}{r}4.2 \text { per } \\
\text { cent }\end{array}$ & 216 & $\begin{array}{r}0.1 \text { per } \\
\text { cent }\end{array}$ & 578 & $\begin{array}{r}1.2 \text { per } \\
\text { cent }\end{array}$ \\
\hline Total & 332 & $\begin{array}{r}100 \text { per } \\
\text { cent }\end{array}$ & $302^{\prime} 435$ & $\begin{array}{r}100 \text { per } \\
\text { cent }\end{array}$ & $48^{\prime} 626$ & $\begin{array}{r}100 \text { per } \\
\text { cent }\end{array}$ \\
\hline
\end{tabular}

Graph 2. Distribution of fatalities and insured losses. Source: Swiss Re, Sigma 1/2005.

Swiss $\mathrm{Re}^{3}{ }^{3}$ shows that disequilibrium. While the major sources of non-life insurance premium are the U.S. (ca. 34 per cent of world premium), Europe (ca. 34 per cent), and Japan (ca. 15 per cent), this is not where the human fatalities occurred in 2004:

\footnotetext{
${ }^{3}$ Swiss Re (2005).
} 
96 per cent of all the victims were in Asia, but only 24.9 per cent of the expected payouts are associated with the region; the U.S., on the other hand, had 2.4 per cent of the victims but over $2 / 3$ of all the expected insurance payouts. This could be taken as an indication that insurance is not always where it should be, or that it might be there but not in the quantities needed. The figures given above demonstrate very clearly that the insurance system is not very homogeneous around the world.

During the recent Monte Carlo Rendez-vous de Septembre of the world reinsurance industry, the large reinsurers estimated the world insurance premia for the year 2005 at almost USD 2,000 billion for the life insurance industry alone. In the developed countries, the average insurance density, that is, total insurance premium per head, is estimated at around USD 3,300. This is a huge amount of money and underlines the importance that insurance plays. In developed economies the total insurance penetration, that is, the share of insurance premia to GDP, is generally greater than 5 per cent and often accounts for more than $1 / 10$ of the whole economy: for example it accounted in the U.S. for 9.36 per cent in 2004, Japan 10.51 per cent, U.K. 12.60 per cent, Germany 6.97 per cent, France 9.52 per cent, or the Netherlands 10.10 per cent.

Such important capital flows lead to huge assets, which the insurance industry controls. The OECD estimates that the financial assets of insurers in the year 2004 amounted to 4,088 billion USD in the U.S., 2,321 billion USD in Japan, and 1,399 billion USD in the U.K., corresponding to 40.5 per cent, 60.3 per cent, and 97.1 per cent of GDP, respectively. The enormous relevance of the insurance industry to the performance of these economies is evident.

Experts at Swiss Re estimate that, overall, world insurance has grown at around 5 per cent per annum (real growth) since the 1950s. With the exception of the leastdeveloped countries (and countries under special circumstances such as the collapse of the Soviet Union), insurance regularly outgrows the general economy as more insurance is demanded when the income and wealth of individuals improve and the interest in protecting assets increases. This underlines the increasing importance to national economies as they develop more wealth.

\section{Insurance and the complex position of the insurer}

In order to better understand the contribution of insurance to the modern economy, we have to understand the complex position that insurers find themselves in when they conduct their business. One of the classical definitions understands insurance as a social or commercial device providing financial compensation for the effect of misfortune, and the payments being made from the accumulated contributions of all parties participating in the scheme. At the core of the insurance mechanism lies this idea about accumulating financial assets for times of potential misfortune. There is a sort of fund in which all insureds will pay an assessed contribution (premium), which is not the same for everybody, depending on the specific risk profile. In return, all those who contribute have the right to ask for an appropriate payment, should an insured event occur. The fund is usually created in such a way that it is highly unlikely that all risks in the scheme are affected at the same time. The insurer determines premium and 
payout mechanisms for everybody contributing to the scheme. He is at the same time a fund manager, an owner, and a risk expert.

In order to understand what can be organised in insurance markets, it is necessary to understand this very complex position: on the one hand, an insurer is a custodian or a treasurer of the established fund; on the other hand, he is the owner of the fund. ${ }^{4}$ Through this setup he has a direct interest in its performance. The two interests cannot easily be aligned and under normal circumstances they would possibly lead to unsolvable problems. However, with the mechanism of insurance, this can be managed. When constituting a fund for future claims, it is usually so well capitalised that in the event of payout there will be some money left over. This money, which is in excess of what has to be paid, can be drawn on because it is the right as owner of the established fund that permits the insurer to profit in such a way from his activity.

At the same time, the obligation as a custodian of the fund means that he will have to pay out for any claims that meet the pre-established criteria. When dealing with questions of insurability and of insurance market mechanisms, this has to be kept in mind because the insurer always has a basic interest in paying out properly established claims, honouring his function as custodian. This obligation, however, also forces him to act in the proper interest of the other parties that form part of the scheme and that might have future claims. Their participation in the insurance scheme constitutes a potential right to draw on the available funds - and more if need be. A potential shortfall has to be made up by the insurer.

The rights of the participants in the scheme need to be protected too, hence the insurer becomes a champion of those rights. It is thus not sufficient to assume that if an insurer refuses to pay out for a disputed claim, he is doing so merely with his own personal interest in mind. He might actively be protecting the other participants in the scheme as custodian.

An insurer also works as a risk expert and risk manager because he has to understand and assess the risks he will accept or decline for the scheme. If somebody buys into that scheme, a new relationship is established and has to be judged on its merits, not least vis-à-vis the existing participants and their risks. Whenever an insurer accepts a new risk into the scheme, this affects everybody who is already in the scheme. It is not just a decision that the insurer takes and where he has a direct obligation concerning the risk per se, he also has an obligation to his other business relations.

For the insurer as risk manager and custodian of a pool of risks, unexpected legal changes present a fundamental problem when they affect the payout scheme. This is especially true if the legal environment changes suddenly in a major way during the period in which risks were accepted and before payments for claims are made. The insurer's liabilities will have already been calculated and the necessary premia to finance those collected before the change in the legal system renders these initial calculations inappropriate. In effect, the insurer will then have placed (voluntarily or not) a bet on the legal development. Often, when policymakers discuss legal changes,

\footnotetext{
${ }^{4}$ The current (very political) discussions in some countries, for example in the U.K., as to how to deal with so-called orphaned funds at life insurance companies and the question whether those belong to policyholders or shareholders, have their origin in this double role that insurance companies play.
} 
these particular effects on the insurance system are not fully reflected upon by the norms setters.

As stated earlier, the insurer defines the conditions for future payout and he establishes some guidelines for behaviour. There is a positive impact too in the contribution that insurance can have on the development of an economy that goes beyond just the risk-sharing mechanism. An insurer is of course an entrepreneur. He is looking for new markets, for business models and strategies; he wants to grow, to establish client relationships, to create an operational infrastructure. He needs welleducated human capital and a sophisticated business infrastructure. All this leads to positive knock-on effects in other parts of the economy.

The insurer is also a key transmitter of preferences in a society. Very often, particular insurance schemes are encouraged to compensate for specific behavioural structures that a society believes it should influence. Tax breaks for taking out life insurance, mandatory third-party liability insurance or long-term care insurance are examples. In some cases the insurance coverage is a precondition for other businesses to operate. And sometimes that pre-condition is not cheap: if one considers operating aircraft, for example, insurance rates are very costly, especially if they are large commercial aircrafts flying over crowded cities.

The insurance sector is subject to very tight regulations; few other industries are as tightly regulated and supervised. This supervision ranges from the initial right of establishment to the types of risks that can be underwritten; it spans the direct protection of consumers to specific contractual arrangements such as reinsurance schemes and other risk transfer mechanisms and how and under which conditions they are permitted; it comprises the language used in contracts as well as general and special requirements for capital held, etc.

All the aforementioned specificities have to be borne in mind when considering the contribution that insurance makes to the modern economy. Insurance is unlike any other business and even the similarities with other financial services providers are limited.

\section{Insurance and the modern economy}

The insurance industry is, of course, a very large employer in any developed and emerging market. The CEA (the European Insurers' Trade Association) estimates that in its member countries alone over $1,000,000$ people are directly employed by some 5,000 insurance companies. ${ }^{5}$ In addition to their own staff, insurers also generate a lot of indirect employment of numerous professionals such as agents, brokers, financial intermediaries and other services companies in areas ranging from IT to transport, from auditors to consultants, etc. They probably account for at least the same amount of indirect employment generated by the sector.

But insurance is not just about employment and the financial compensation of victims; insurance is also the central part of the capitalisation process of a modern

\footnotetext{
${ }^{5}$ CEA (2006).
} 
economy. It creates huge capital assets as we saw in the preceding section. The money coming from insurance, due to the nature of the contracts and the sometimes very long time horizons involved, usually stays in the financial market of a given economy for quite some time. It is not fickle investment capital that rushes around looking for quick gains, it is oriented toward the medium to long term. It thus plays a special role underpinning the growth of an economy. ${ }^{6}$ The insurance mechanism furthermore allocates assets according to market forces where needed and this in a largely stable environment. It also allows a process of maximising returns according to market forces that are directly related to the risk structures we find.

Another key point is the buffer function of insurance in the modern economy. This buffer function is also of great importance for a modern economy because it allows the filtering out of sudden surges in financial needs linked to a disaster for all insured players that might otherwise be pushed into bankruptcy. The existence of insurance gives the opportunity to plan ahead with more certainty, avoiding or mitigating specific risks that are deemed to be threatening to the general business process.

Even when submitted to large stress, the insurance sector has a tendency to be more stable than, for example, banking. Let us briefly consider how an insurance crisis plays out compared to a banking crisis. In a banking crisis the most feared phenomenon is a run on a bank. The effect is immediate and it has to be stopped, otherwise it will destroy the economy as ever more funds are withdrawn and the capacity of the banking system to cope with the reduction in assets diminishes rapidly. A major crisis in the insurance sector develops totally differently as there usually is time to react. Insurance companies might even become insolvent for a certain time without having to stop their activity. After a major crisis they could start paying out claims while recapitalising at the same time and using parts of the premium income for future risks to finance current liabilities. While this is not a desirable situation and both insurers and their regulators would want to avoid it whenever possible, in a moment of utmost stress on the financial system, the resilience is much higher for insurers than for banks due to this flexibility.

Insurance is one of the rare mechanisms that allow for the spreading of risk over time. This risk spreading over time can involve very long periods and works even from one generation to the next. There are very few other industries that have such long time horizon as the insurance industry. Who would think more than 50 years ahead? Perhaps the builders of a nuclear power plant, but few others. And insurance has to consider periods of up to a century. French lady Jeanne Calment lived to the age of

\footnotetext{
${ }^{6}$ This is no trivial point. Insurance market activity, both as a financial intermediary and a provider of risk transfer and indemnification, should contribute to economic growth by allowing different risks to be managed more efficiently and by mobilizing domestic savings. In his paper, "Does insurance market activity promote economic growth? Country study for industrial and developing countries", Marco Arena tests whether there is a causal relationship between insurance market activity (life and non-life insurance) and economic growth. Using the generalized method of moments for dynamic models of a panel data of 56 countries and for the 1976-2004 period, he finds robust evidence of a causal relationship between insurance market activity and economic growth. Both life and non-life insurance have a positive and significant causal effect on economic growth (Arena (2006)).
} 
120 years, and had she taken out a life insurance policy around the time she was 20 years old, this policy would have been in force for a full century.

Insurance has a doubly positive impact on the savings of an economy: Firstly, it increases the general savings rate (especially through the existence of life insurance products) thus creating deeper markets and allowing for more investments. Secondly, it decreases the level of unnecessary precautionary savings (savings often not available to capital markets) and stimulates investment and consumption by reducing bound (and therefore unproductive or less productive) capital. Insurance thus helps to provide more working capital to an economy because people do not have to protect themselves against the eventuality of, for example, their home being destroyed by a fire. They just have to secure adequate cover through a fire insurance policy and be ready to pay a much lower amount of money over a longer period - a totally different mechanism. This means that the money saved in the process can be allocated to other things, more in line with the preferences of the individuals and more productively. Insurance mechanisms transform dormant capital into free capital.

Insurance markets also expose myopic and other irrational behaviour of agents and allow for the correcting of this behaviour. Examples for these corrections are often found in the subvention of certain insurance lines and in the existence of mandatory coverage for specific risks, for example third-party liability cover.

\section{The effects of insurance beyond the financial dimension}

As we saw in the preceding sections, insurance plays an important role in the financial domain. However, its impact beyond the purely financial and on economic growth is as relevant to a modern economy.

Insurance, when it is provided, gives independence to people and increases their capacity of self-reliance. The ability to cope with adverse effects, which are often unexpected and might occur at the least opportune moment, is strengthened. This creates a very strong impact on future development because it enables people to become and stay active as they do not have to worry about all possible adverse effects that a certain activity might entail. While there is a direct economic effect through the financial protection of assets, there is also an additional consequence: peace of mind. People tend to behave differently - and we suppose more positively - when they know that certain risks are taken care of. This is a psychological rather than a financial effect accompanying the purchase of insurance. The counterargument here is the existence of moral hazard, where individual behaviour becomes more risky due to an existing insurance coverage. It is difficult to assess the exact impact of both the effects, a positive one that reduces risky behaviour and a negative one that would encourage it. Insurance companies have found ways of dealing with the problem of moral hazard by implementing mechanisms that protect the insurance scheme from undue exploitation and bad risks. ${ }^{7}$

\footnotetext{
${ }^{7}$ The details of these mechanisms shall not be discussed in this paper.
} 
Once people are insured, they become members of a solidarity group that goes far beyond their own circles. In the past, a family or village, maybe an extended family or a network of little villages could work together to share certain risks and compensate those that suffered from ill fortune. However, the scope of a risk-sharing group was usually limited, if not by geographic realities then by the impossibility to know and understand the risk exposure of an unknown partner. Through insurance, however, the risk-sharing group can be extended and people who participate in it need not know everybody else in the group as they delegate the task of organising the group to an expert, the insurer. Consequently, the group can take on a whole new extension where risks can be pulled from different parts of the world and even from different risks and different lines of businesses. The resulting risk pool is organised ex ante, that is, before a disaster happens, to support the others when and if it happens regardless of the formal ties that participation in the scheme might or might not share beyond taking part in the scheme. This is an important mechanism that would not exist at such a sophisticated level without insurance.

Insurance companies are information providers, knowledge carriers and training centres for economies with highly complex products that need a lot of financial and non-financial knowledge: a fire insurer needs to know about building codes and materials, a flood insurer about geographic feature and meteorological conditions, a health insurer about medicine and pharmacology, etc. This bundling of superior knowledge has a positive effect on and is of a significant value for the development of economies and of societies. Firstly, insurers need well-formed experts in risk matters who work for them and so they have an interest in the education and formation of an experienced workforce. Through their work and the specialists needed to run their business, better understanding about risk issues is introduced into a society. Secondly, they create more knowledge about risk management, risk assessment and understanding vulnerabilities on the side of their potential customers, consulting for example about risk exposures and prevention, mitigation strategies and possible solutions. The sale of an insurance product is closely tied to a risk assessment exercise by the insurer, which is usually shared with the prospective client. This introduction and spreading of knowledge and understanding is valuable not just for the insurance markets, but for the general development of the economy because risk assessment, risk management, prevention mechanisms, etc., are very much a precondition of and a driver for sustained growth. And its absence can be disastrous for many undertakings.

It is interesting to note the high correlation between the existence of insurance in certain markets and the profusion of preventive measures. This apparently not only affects those parts of the economy where insurance is active but also in a more general way as certain risk management practices spread and are more widely adopted. Even legislators seem to react to this mechanism because more sophisticated legislation tends to appear in tandem with a more sophisticated insurance market. While this conclusion is merely based on observation, it would be interesting to obtain research results that could substantiate this view.

Insurance not only affects ex ante behaviour such as more efficient prevention, but also ex post behaviour. The information and knowledge that exist through insurance allow, for example, speedier reconstruction after natural or man-made disasters. Knowing that the affected parties have insurance policies that cover an event and 
ensure enough funds to sustain rebuilding efforts, the work on a disaster site becomes more attractive or even possible in the first place. Larry Silverstein, the owner of the World Trade Centre in New York that was destroyed in the attacks of 11 September 2001, made a very clear case for reconstruction. He said that the availability of the insurance payout was directly linked to his reconstruction effort. But it is not only the payout that has an effect. Already the understanding by all parties that a risk is covered leads to positive results. Let us consider another example: After a hurricane, if it is known that homeowners have the money to pay for new roofs, the construction companies will be standing at the ready in order to provide the services because they know that they are going to be paid eventually. This means that the existence of an insurance scheme creates another reservoir of activities, of services that are ready to step in, in case of a disaster. They would not be available as a backup if people lost everything due to a disaster and did not have the opportunity to rebuild.

The existence of an insurance market fosters an industry around it: offers for preventive measures and services, damage assessments, legal advice and assistance, claims handling services, relief and reconstruction mechanisms, etc. These services are not only available to insureds but benefit the whole economy. They also create jobs, much like the insurance industry does, a very large employer in most developed economies. Work in the insurance industry is quality work, as insurance jobs are highskilled modern services workplaces with low absenteeism and few accidents. They are well-paying jobs for a large number of persons with varied backgrounds.

Insurance also has a very positive interaction with the public domain because major incidents could result more easily in large disruptions and even in civil unrest in the absence of mechanisms to compensate the affected population. The aforementioned 11 September attacks caused economic losses to the city of New York in the order of 100 billion USD, as calculated by McKinsey. The insurance payout is estimated by Swiss Re and Munich Re to be around 30 billion USD, a significant share of it in the form of life insurance payments to distressed families who lost their prime income earner or in the form of business interruption policies which guaranteed continuing income despite the loss of a key source of revenue for shop owners. It is only too obvious that these payouts helped mitigate the effects of the disaster on the general population. As the New York experience showed, after large disasters, the insurance infrastructure allows for easy piggybacking of additional initiatives like impact assessment and information sharing, public disaster information and relief centres, and the channelling of humanitarian help, etc. The disaster relief centre, created by the Insurance Information Institute in New York grouped and coordinated 25 different organizations, all with the aim of helping to cope with the aftermath of the terrible event.

The counterexample to this positive post-catastrophe scenario could to a certain extent be the aftermath of Hurricane Katrina that struck New Orleans in September 2005. The storm and the floods that followed not only took hundreds of lives but they also destroyed the livelihood of many people and families who had no protection in the form of insurance. Additionally, the insurance infrastructure in the state of Louisiana was much inferior to that of the state of New York in 2001. The violence and looting that took place in the days after the hurricane were linked by some media commentators, at least in part, to the fact that very few of the poorer families could expect insurance payouts to help them with reconstructing their lives. 
As we can easily observe, the existence of insurance and the protection and prevention schemes that go with it have a noticeable impact on public life. People will generally not accept the same lax attitude towards risk management of governments if they are fully aware of the consequences. The nuclear debates in the 1970s took a different turn when the high risks associated with this technology became more apparent and publicly known. Insurers and their business partners also provide a lot of the knowledge concerning climate change and natural disasters like storms and earthquakes. Through their work the public risk debates are different, usually more informed but also intense, and they often play a direct role in stimulating less risky behaviour. Safety campaigns like "Safe driving" or "Safety at Work" are very positive as they reduce fatalities and accidents. In France, the recent nationwide safe driving campaign was supported in a major fashion by the FFSA, the French insurers' association. It reduced road fatalities by about a quarter in the space of less than one year!

Insurers are sometimes considered as very boring because they want people to buckle up in their car and they do not want them to go bungee jumping. People can still decide not to buckle up but at least they are aware of the dangers and that sort of behaviour is becoming less acceptable and less common. The possibility to associate insurance premium directly with the risk exposure, especially where individual behaviour plays a major part, is a powerful tool. The awareness about insurance premia going up because of risky behaviour is not lost on the cost conscious consumer - with a generally positive result for the economy at large.

\section{Conclusion}

Insurance is unfortunately often considered an unnecessary expense by potential buyers, particularly if they are uninformed. It is also seen as a superior good by economists, which becomes regularly and widely available only after many other needs are covered. This is wrong! Insurance is not an unnecessary expense, but if done right, an investment in the protection of assets. It is not a superior good in the sense that it is a luxury and should only be considered after many other issues; it is often the precondition for (economic) action and it is intertwined with the most basic human needs and aspirations. The availability of insurance has important positive effects and externalities that go far beyond the purely financial. In many cases, being uninsured is in the long-term the most costly option - to an individual, to an economy, to a society.

This contribution has described the positive role and impact that insurance has in a modern economy. Unfortunately, many of the above constructive and helpful effects are neglected or not fully considered in all their ramifications when it comes to policy decisions. Despite the existence of mutuality and risk-sharing schemes for hundreds of years, and, in its modern form for arguably more than a century, insurance is still not fully understood by all key stakeholders. This is not only a misfortune from an intellectual point of view but a real waste of possibilities to develop modern economies in the most efficient way.

After all the good that has been written here about the insurance activity and its risk management and transfer mechanisms, the question beckons: Are there negative 
effects too, and what are they? Yes, there are some, but they shall be discussed in another paper.

\section{References}

Arena, M. (2006) Does insurance market activity promote economic growth? Country study for industrial and developing countries, World Bank Policy Research Working Paper No. 4098, Washington, DC.

CEA (2006) The Contribution of the Insurance Sector to Economic Growth and Employment in the $E U$, Brussels: CEA.

Swiss Re (2005) 'Natural catastrophes and man-made disasters in 2004', Sigma no. 1/2005.

Swiss Re (2006) 'World insurance in 2005', Sigma no. 5/2006.

\section{Further reading}

Hardin, R. (1958) 'Contributions of life insurance to capital formation in the South', The Journal of Insurance 25: 47-52.

Kugler, M. and Ofoghi, R. (2005) Does insurance promote economic growth? Evidence from the U.K., University of Southampton Paper, July 2005.

Liedtke, P. (2005) 'L'assurance et son rôle prépondérant dans les économies modernes', Revue Risques 63: $105-108$.

Munich, Re. (2006) Annual Review - Natural Catastrophes 2005, Knowledge Series - Topics Geo, Munich: Munich Re.

Outreville, J.F. (1990) 'The economic significance of insurance markets in developing countries', Journal of Risk and Insurance 57: 487-498.

Skipper, H.D. (1997) Foreign insurers in emerging markets: issues and concerns, Occasional Paper 97-2, Center for Risk Management and Insurance, Atlanta, Georgia.

Ward, D. and Zurbruegg, R. (2000) 'Does insurance promote economic growth? Evidence from OECD countries', 67: 489-506.

Webb, I. and Skipper, H.D. (2002) The effect of banking and insurance on the growth of capital and output, Working Paper 02, Center for Risk Management and Insurance, Atlanta, Georgia.

Webb, I. (2006) Assessment on how strengthening the insurance industry in developing countries contributes to economic growth, Final Report to USAID.

\section{About the Author}

Patrick M. Liedtke is Secretary General and Managing Director, The Geneva Association. 